\title{
Social and individual behavior of female spiny mice (Acomys cahirinus) paired with sexually experienced and inexperienced males
}

\author{
SUE LYNN ANDRES and RICHARD DENI \\ Rider College, Lawrenceville, New Jersey 08648
}

\begin{abstract}
Seven sexually inexperienced adult female spiny mice (Acomys cahirinus) were observed during heterosexual pairings with either sexually inexperienced or experienced male companions. The behaviors recorded included self-grooming, companion-body grooming, companionanogenital contact, locomotion, immobility, and pursuit of the male. Each observation session lasted $15 \mathrm{~min}$ and was separated into three 5 -min periods for analysis. The type of companion, sexually inexperienced or experienced, and the session number (Day 1, Day 2) were additional within-subjects variables. Results indicated that individual behavior (locomotion and selfgrooming) was inhibited by the presence of the inexperienced male companion. Social behavior (anogenital contact, pursuit) was facilitated by the presence of the inexperienced male companion, but only for the first 5-min period of exposure per session. These findings were discussed as evidence that female spiny mice discriminate the behavior of male companions and may regard inexperienced males more as intruders than they regard sexually experienced males.
\end{abstract}

Aggressive and dominance behaviors of female spiny mice (Acomys cahirinus) have been shown to be affected by physiological control, both directly and indirectly. Direct physiological control was implicated in the finding by Moore, McRainey, and Hicks (1981) that REM sleep deprivation facilitated approach, chasing, biting, and displacement behavior in females during interaction with other female spiny mice. Indirect physiological control was implicated by Porter (1976), who showed that home-cage stimuli (presumably resident odor cues) affected the display of agonistic behavior by females. Porter reported sex differences in the aggressive behavior of spiny mice observed in opposite-sex pairs. Tests occurred in the home cages of both the male and female of each pair. Females tested in their home cages were more aggressive and dominant over their male companions. Females and males were equally aggressive when tested in the male's home cage, and less overall aggression was seen in male cages. These data suggest that females regarded males as intruders on their territory, but males did not regard females as intruders.

The purpose of the present study was to determine if the social and individual behavior of female spiny mice, observed in opposite-sex pairs, would be affected by the level of previous sexual experience of the male companion. In general, it was predicted that sexually inexperienced males would be treated more like intruders by

Address reprint requests to Richard Deni, Rider CollegePsychology, Lawrenceville, New Jersey 08648. We thank Richard H. Porter, Comparative Development Laboratory, George Peabody College of Vanderbilt University, for help in establishing our breeding colony of Acomys cahirinus. female mice. As a result, female behavior would be characterized by less self-grooming and individual locomotion, and more social contact and pursuit.

\section{METHOD}

\section{Subjects}

Seven adult female spiny mice were used as subjects. They were housed individually in steel cages after weaning at 30 days of age and fed Purina 5012 chow and water. Subjects were at least 150 days old at the start of the study. Two types of male companions were used in this study, including seven sexually inexperienced and seven sexually experienced adult spiny mice. Male companions were at least 150 days old and fed Purina 5012 chow and water. Inexperienced male companions were housed individually in steel cages after weaning at 30 days. Experienced male companions were paired at 30 days with a female of the same age and housed in a standard plastic rodent cage with wire top and pine shavings as bedding material. Experienced males remained paired with the same female for a period of at least 1 year and sired at least five litters during that time. Subjects and companions were housed in the same colony room maintained at $70^{\circ} \mathrm{F}-73^{\circ} \mathrm{F}$, with day length regulated by outside light cues.
Apparatus
Opposite-sex pairs were placed in a rectangular clear plastic rodent cage with a clear plastic cover. This cage was located on the floor of a small test room apart from the colony room, illuminated by both fluorescent and incandescent light sources. A video camera was mounted on a tripod and placed above the test cage to record the behavior of subjects from that perspec- tive. Observations were recorded on video cassette for later playback and coding. Extraneous sounds outside the test room were masked by white noise. Air temperature inside the test room varied from $70^{\circ} \mathrm{F}$ to $73^{\circ} \mathrm{F}$. During playback of video- tapes, electronic counters and timers were used to record specific social and individual behaviors of the subjects. 
Procedure

Opposite-sex pairings and observations of the female subjects were carried out over a 30-day period with all observations videotaped between 0630 and $0800 \mathrm{~h}$. When a pairing and observation required an inexperienced male companion, the female subject and the male companion were taken from their individual cages and placed together in the plastic test cage in the test room. When a pairing and observation required an experienced male, the female subject was taken from its individual cage and the male companion was separated from its mated female and placed with the subject in the plastic test cage. Each female subject was repeatedly tested with a particular inexperienced and experienced companion. Each test session consisted of three consecutive 5-min periods. Female subjects were tested with inexperienced male companions during two daily sessions followed by experienced male companions during two daily sessions. The following behaviors were recorded during playback of videotapes: (1) "self-grooming," including cleaning the fur and sniffing or touching the body, (2) "companion-body grooming," including cleaning the companion's fur and sniffing or touching the companion's body (excluding anogenital region), (3) "companion-anogenital contact," including sniffing or touching the companion's anogenital region, (4) "locomotion," defined as walking or running, (5) "immobility," defined as the absence of locomotion, and (6) "pursuit" of companion, defined as chasing the male. All measures were durations recorded to the nearest $.1 \mathrm{sec}$. Periodic measures of interobserver reliability were obtained. Percent agreement measures were consistently above $95 \%$ on all dependent variables.

\section{RESULTS}

All subjects were sexually unreceptive throughout all test pairings with male companions, and no instances of copulation were observed. The duration scores for the six dependent measures were analyzed using a threefactor within-subjects analysis of variance for each dependent measure. The three hierarchical withinsubjects factors were (1) type of male companion (sexually inexperienced or experienced), (2) test day (Day 1 or Day 2), and (3) test session period (first, second, and third 5-min period). When appropriate, specific comparisons were made using Newman-Keuls tests.

\section{Self-Grooming}

Analysis of variance revealed a significant main effect for type of male companion $[F(1,66)=24.25, p<.001]$ and a significant three-way interaction between type of companion, test day, and session period $[\mathrm{F}(2,66)=$ $4.26, \mathrm{p}<.025]$. Means and standard deviations for duration of self-grooming are shown in Table 1 for the main effect and three-way interaction. Female subjects showed significantly longer durations of self-grooming when observed with experienced male companions compared with inexperienced male companions. Threeway interaction cell means shown in Table 1 reveal two functional variations in behavior over the three session periods within each test day. Duration of self-grooming peaked during the second period on Test Day 1 with inexperienced males, but dipped during the second period on Test Day 1 with experienced males. However,
Table 1

Means and Standard Deviations for Duration of Self-Grooming (in Seconds) by Female Spiny Mice

\begin{tabular}{|c|c|c|c|c|c|}
\hline \multirow{3}{*}{\multicolumn{2}{|c|}{ Within-Subjects Factor }} & \multicolumn{4}{|c|}{ Type of Male Companion } \\
\hline & & \multicolumn{2}{|c|}{ Inexperienced } & \multicolumn{2}{|c|}{ Experienced } \\
\hline & & Mean & SD & Mean & SD \\
\hline \multicolumn{6}{|c|}{ Main Effect: Type of Male Companion } \\
\hline & & 27.9 & 11.1 & 42.9 & 19.0 \\
\hline \multicolumn{6}{|c|}{ Three-Way Interaction Effect } \\
\hline Day 1 & $\begin{array}{l}\text { First Period } \\
\text { Second Period } \\
\text { Third Period }\end{array}$ & $\begin{array}{l}26.9 \\
33.6 \\
26.2\end{array}$ & $\begin{array}{l}6.5 \\
9.9 \\
9.2\end{array}$ & $\begin{array}{l}48.1 \\
29.8 \\
48.9\end{array}$ & $\begin{array}{l}23.8 \\
16.4 \\
19.4\end{array}$ \\
\hline Day 2 & $\begin{array}{l}\text { First Period } \\
\text { Second Period } \\
\text { Third Period }\end{array}$ & $\begin{array}{l}35.4 \\
22.0 \\
23.2\end{array}$ & $\begin{array}{l}11.6 \\
13.8 \\
11.0\end{array}$ & $\begin{array}{l}42.5 \\
46.0 \\
42.3\end{array}$ & $\begin{array}{l}16.6 \\
22.1 \\
14.1\end{array}$ \\
\hline
\end{tabular}

Table 2

Means and Standard Deviations for Duration of Companion Anogenital Contact (in Seconds) by Female Spiny Mice

\begin{tabular}{|c|c|c|c|c|c|c|}
\hline \multirow{3}{*}{$\begin{array}{c}\text { Session } \\
\text { Period }\end{array}$} & & & \multicolumn{4}{|c|}{ Two-Way Interaction } \\
\hline & \multicolumn{2}{|c|}{$\begin{array}{l}\text { Main Effect: } \\
\text { Session Period } \\
\end{array}$} & \multicolumn{2}{|c|}{$\begin{array}{c}\text { Inexperienced } \\
\text { Male Companion }\end{array}$} & \multicolumn{2}{|c|}{$\begin{array}{c}\text { Experienced } \\
\text { Male Companion }\end{array}$} \\
\hline & Mean & SD & Mean & SD & Mean & SD \\
\hline 1 & 30.9 & 19.0 & 38.2 & 19.8 & 23.7 & 15.5 \\
\hline 2 & 23.9 & 13.5 & 20.1 & 8.3 & 27.6 & 16.8 \\
\hline 3 & 17.6 & 11.2 & 17.6 & 8.8 & 17.6 & 13.6 \\
\hline
\end{tabular}

these within-session differences were not significant according to specific-comparison tests.

\section{Companion-Body Grooming}

No significant effects were obtained for this dependent measure. Average durations were highly stable and ranged between 18.0 and $30.7 \mathrm{sec}$ across all factor combinations in the analysis.

\section{Companion-Anogenital Contact}

Analysis of variance revealed a significant main effect for session period $[F(2,66)=7.41, p<.005]$ and a significant two-way interaction between type of male companion and session period $[\mathrm{F}(2,66)=5.23, \mathrm{p}<.01]$. Means and standard deviations for duration of companionanogenital contact are shown in Table 2. Average durations of behavior decreased over the three session periods. Specific-comparison tests showed that duration of contact during the first period was significantly greater than duration of contact during the second or third period $(p<.05)$. Average durations of contact as a function of the significant two-way interaction showed a decreasing trend over periods during pairings with an inexperienced male companion, but a curvilinear trend during pairings with an experienced male. Specificcomparison tests showed that contact during the first period with the inexperienced male was significantly greater than during either the second or third period 
$(p<.05)$, but the same pattern was not obtained for period differences with the experienced male.

\section{Locomotion}

Analysis of variance revealed a significant main effect for type of male companion $[F(1,66)=13.53, p<.001]$. Means and standard deviations for duration of locomotion (in seconds) were as follows: (1) inexperienced male companion, mean $=154.0(\mathrm{SD}=46.5)$ and $(2)$ experienced male, mean $=124.0(\mathrm{SD}=44.9)$. Female subjects showed significantly more locomotion during pairings with inexperienced males.

\section{Immobility}

Analysis of variance revealed a significant main effect for session period $[F(2,66)=3.67, p<.05]$. Means and standard deviations for duration of immobility (in seconds) were as follows: (1) first period, mean $=52.0(\mathrm{SD}=41.9),(2)$ second period, mean $=$ $75.2(\mathrm{SD}=55.0)$, and (3) third period, mean $=76.8$, $(\mathrm{SD}=51.7)$. There was an increasing and asymptotic function of duration of immobility over time within a session. Specific-comparison tests showed average duration for the first period was significantly lower than that for either the second or third period $(p<.05)$.

\section{Pursuit of Companion}

Analysis of variance revealed a significant two-way interaction between type of male companion and session period $[\mathrm{F}(2,66)=3.49, \mathrm{p}<.05]$ and a significant three-way interaction between type of companion, test day, and session period $[F(2,66)=3.62, p<.05]$. However, no interaction cell comparisons were significant. Means and standard deviations for duration of pursuit of companion are shown in Table 3 for the twoway and three-way interactions. The linear trend in mean durations as a function of session period during

Table 3

Means and Standard Deviations for Durations of Pursuit of Male Companions (in Seconds) by Female Spiny Mice

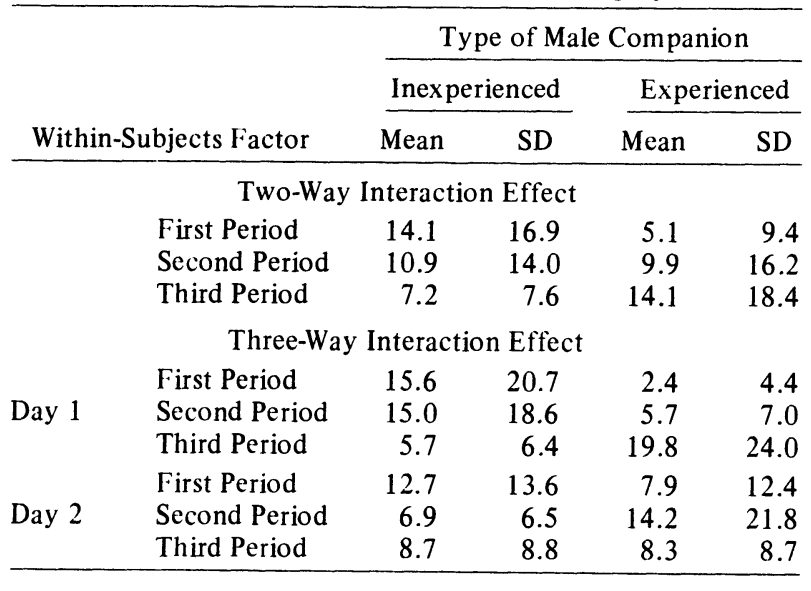

testing with inexperienced males was the opposite of that for testing with experienced males. Duration of pursuit of males by females declined over time when the male was inexperienced but increased over time when the male was experienced. Furthermore, this trend was present for both test days during pairings with inexperienced males, but only on Test Day 1 during pairings with experienced males.

\section{DISCUSSION}

The present findings suggest that female spiny mice treated sexually inexperienced males more like intruders than they did sexually experienced males. This is somewhat inconsistent with data on female aggression toward experienced males in golden hamsters (Mesocricetus auratus). Ciaccio, Lisk, and Reuter (1979) reported high levels of female aggression toward sexually experienced male hamsters, particularly in nonreceptive females.

The individual behavior of female spiny mice observed in the present study was inhibited by the presence of an inexperienced male companion. For example, during five of six 5-min observation periods, females exhibited less self-grooming in the presence of inexperienced males than in the presence of experienced males. Significantly less individual locomotion by females was shown in the presence of the inexperienced male companion. The social behavior of these females was either unaffected by male sexual experience, as in the case of companion-body grooming, or facilitated by the presence of an inexperienced male, as in the case of anogenital contact and pursuit by females during the first 5-min observation period. However, as exposure time progressed, for example, Period 3 data, the facilitation effect on pursuit behavior by females either reversed itself or disappeared altogether. The decline over time in pursuit of inexperienced males by female spiny mice is not likely to have been an example of a mating-induced reduction in proceptive behavior (cf. Steel, 1979), since no copulation was observed during any of the pairings.

The pattern of present findings supports the contention that sexually inexperienced males were treated more like intruders than experienced males were. In addition, they provide further evidence that changes in female behavior during heterosexual pairings may be determined by differences in the behavioral history or condition of male companions and the ability to make discriminations based on the differences. Studies supporting this reasoning include reports that female house mice (Mus musculus) behaved differently toward male conspecifics based on the odor and physiological condition of the males (cf. Hayashi \& Kimura, 1978), that the familiarity of a male to female deer mice (Peromyscus maniculatus) potentiated heterosexual interactions (Dewsbury, 1979), that female Mongolian gerbils (Meriones unguiculatus) are more aggressive with an unfamiliar compared with a familiar male (Agren \& Meyerson, 1977), and that female hamsters of the genus Mesocricetus prefer conspecific males over nonconspecific males of the same genus (Murphy, 1977).

\section{REFERENCES}

Agren, G., \& Meyerson, B. J. Influence of gonadal hormones and social housing conditions on agonistic, copulatory, and related socio-sexual behaviour in the Mongolian gerbil (Meriones unguiculatus). Behavioural Processes, 1977, 2, 265-282.

Ciaccio, L. A., Lisk, R. D., \& Reuter, L. A. Prelordotic behavior in the hamster: A hormonally modulated transition 
from aggression to sexual receptivity. Journal of Comparative and Physiological Psychology, 1979, 93, 771-780.

DewsBury, D. A. Copulatory behavior in deer mice (Peromyscus maniculatus): II. A study of some factors regulating the fine structure of behavior. Journal of Comparative and Physiological Psychology, 1979, 93, 161-177.

Hayashi, S., \& Kimura, T. Effects of exposure to males on sexual preference in female mice. Animal Behaviour, 1978, 26, 290-295.

Moore, J. D., McRainey, L., \& Hicks, R. A. REM sleep deprivation increases dominance behaviors in female spiny mice. Bulletin of the Psychonomic Society, 1981, 17, 246-248.
MurPhy, M. R. Intraspecific sexual preferences of female hamsters. Journal of Comparative and Physiological Psychology, $1977,91,1337-1346$.

Porter, R. H. Sex-differences in the agonistic behavior of spinymice (Acomys cahirinus). Zeitschrift für Tierpsychologie, 1976, 40, 100-108.

SteEl, E. Short-term, postcopulatory changes in receptive and proceptive behavior in the female Syrian hamster (Mesocricetus auratus). Hormones and Behavior, 1979, 12, 280-292.

(Received for publication March 3, 1982.) 